\section{Financial Reporting Quality and Sustainability Information Disclosure in Brazil}

\author{
João Antônio Salvador de Souza ${ }^{1, *}$ \\ ${ }^{1}$ Universidade Federal de Santa Catarina, Florianópolis, SC, Brasil \\ Leonardo Flach ${ }^{1,}$ (1) \\ ${ }^{1}$ Universidade Federal de Santa Catarina, Florianópolis, SC, Brasil \\ José Alonso Borba ${ }^{1, \Omega}$ \\ ${ }^{1}$ Universidade Federal de Santa Catarina, Florianópolis, SC, Brasil \\ Cleber Broietti ${ }^{1, ¥}$ \\ ${ }^{1}$ Universidade Federal de Santa Catarina, Florianópolis, SC, Brasil
}

\section{ABSTRACT}

Currently, businesses face an information disclosure approach involving the triple bottom line (social, environmental, and financial). This paper aims to investigate the relationship between corporate social responsibility (CSR) information and financial reporting quality (FRQ). We argue that CSR companies behave differently in preparing financial accounting reports. Recent literature supports this theme, providing two distinct hypotheses: transparent financial reporting and retreatment. We used a sample of 1,181 companies from the years 2012 to 2016 to identify if socially responsible companies have better quality financial accounting information. In contrast to the hypotheses raised, we didn't find a relationship between the CSR disclosures and the FRQ proxies. This suggests that sustainable companies do not explain lower or higher levels of earnings management. Our findings remain unchanged when we replace results management through discretionary accruals for manipulations of operating activities. Estimates with comparable samples also didn't change the interpretations of the results.

\section{KEYWORDS}

Corporate social responsibility, Financial reporting quality, Earnings management
CORRESPONDING AUTHOR

*João Antônio Salvador de Souza Email: jass26salvador@gmail.com ${ }^{\dagger}$ Leonardo Flach

Email: leonardo.flach@gmail.com

$\Omega$ José Alonso Borba

Email: jalonsoborba@hotmail.com

$¥$ Cleber Broietti

Email: cleberbroietti@gmail.com

Received: 16/07/2018.

Revised: 17/10/2018.

Accepted: 25/02/2019.

Published Online: 25/09/2019.

DOI: http://dx.doi.org/10.15728/bbr.2019.16.6.2 


\section{INTRODUCTION}

A combination of accounting measurements and disclosures provide managers legitimate possibilities to present financial statements consonant with their goals. Their discretion in accounting choices, based on the strict field of law and accounting principles, is recognized as earnings management (EM), and relates to the quality of reported financial information (Fields, Lys, \& Vincent, 2001). Recent studies also relate the FRQ with practices for CSR.

The extent of the relevance of sustainability generally supports the subject of analysis in companies (Yip, Staden, \& Cahan, 2011). According to ethical theories, companies attempt to be ethically responsible by demonstrating this behavior in general society (Hoffman, 1986). From this perspective, companies with CSR practices should aim for profit by obeying legal obligations (Donaldson \& Preston, 1995; Jones, 1995). Furthermore, CSR activities can build a positive image of the company before its entrance into the market (Lev, Petrovits, \& Radhakrishnan, 2010). This theoretical framework supports the hypothesis that socially responsible companies tend to present more reliable and transparent financial reporting.

As a proxy for FRQ, and as a financial performance indicator, gains can be manipulated in a discretionary manner to meet expectations. Low-quality financial reporting caused by EM can distort CSR activities' usefulness. In this conjecture, opportunistic managers use CSR activities as a retreatment tool to hide the harmful impacts of their corporation's actions (Hemingway \& Maclagan, 2004). To externalize the agency problem (Krüger, 2015), managers involved in CSR actions have incentives to maximize their personal well-being with opportunistic financial reports. Hobson and Kachelmeier (2005) point out that low-quality earnings can be an incentive to externalize CSR practices.

Related studies provide inconsistent evidence that reduces the understanding of this relationship. Chih, Shen, and Kang (2008) report that the relationship between CSR and the adopted FRQ depends on the EM measure. Prior, Surroca, and Tribó (2008) confirmed CSR activities' positive impact on the management of regulated firms' gains, but the result does not apply to unregulated companies. Yip et al. (2011), found an anecdotal relationship, according to the sector analyzed, between CSR and EM through discretionary accumulation (DA). Already, recent studies utilizing the scenario that is not mainstream, have demonstrated that the EM, through DA (Laksmi \& Kamila, 2018) and manipulations of operating activities (Kolsi \& Attayah, 2018) don't have any effects on CSR disclosures. In this context, this research aims to verify the relationship between CSR and FRQ in companies listed on the Brazilian stock market, based on the dichotomous assumptions identified in the literature.

Brazil's stock market is characterized by a concentrated ownership structure in an emerging country with a legal environment characterized by the poor protection of minority shareholders. Additionally, environmental and social information disclosures have become more frequent in Brazil over the last decade. The country differs from other emerging countries, as this presents a sustainability index (the ISE) calculated by the stock exchange (the B3). The ISE began in 2005, and aims to align sustainable development investments, stimulate corporate ethical responsibility, and drive companies to provide better quality sustainable information.

The inconsistent results documented in the literature can be complemented by this study, which explores the relationship between CSR disclosure and FRQ in an out-of-mainstream scenario. For the researched environment, we find that CSR disclosure is not used as a subterfuge to deceive the market, nor as a form of legitimation. In a way, we contribute to the understanding that other channels, other than CSR disclosure, can be used as mechanisms associated with EM. We suggest, in the discussion of the results, to analyze the extent to which financial characteristics 
and institutional variables interfere in the relationship between CSR disclosure and FRQ. Our main evidence suggests that sustainable companies don't explain lower or higher levels of DA. This may be useful in the academic discussion of managerial opportunism. In addition, the discussions raised can help standard-setters and regulators better understand the behavior of companies that disclose information about socially responsible activities. It is seen that, from the perspective of conflict of interest and based on this research, sustainable companies seem not to care about the reduction of EM.

\section{LITERATURE REVIEW}

\subsection{Corporate Social Responsibility (CSR) and Financial Reporting Quality (FRQ)}

Sustainability is a complex concept, and presents differing views on theoretical frameworks. The CSR concept is a way for companies to commit with all stakeholders inside and outside the organization (stakeholders), without focusing only on partners and shareholders (stockholders). Carroll (1979) explains that businesses' social responsibility is comprised of the economic, legal, ethical, and discretionary perspectives that society presents to the organization. By this definition, companies should aim to profit according to legal requirements, and act as ethical and appropriate corporate citizens.

Within this theoretical framework - which provides a direction to and foundation for the existence of CSR activities and the dissemination of economic, social, and environmental information - Garriga and Melé (2004) incorporate various theories to classify CSR into four groups: ethical, political, integrative, and instrumental theories.

The first set of theories explains that companies should accept social responsibility as an ethical obligation (Carroll, 1979; Donaldson \& Preston, 1995; Jones, 1995) and promote what is ethically acceptable for society. Regarding political theories, companies must seek a formal alternative to publicize the improvements they desire to insert in the community (Kim, Park, \& Wier, 2012). Business success under integrative theories is a condition that involves by integrating the business' social demands (Carroll, 1979; Swanson, 1995). Finally, in considering the economic objectives arising from instrumental theories, for example Friedman (1970), it is observed that CSR activities are a means by which stockholders receive added wealth. In this context, within the CSR theories of groups, the legitimacy and agency theories and the theory of stakeholders exist at the individual level.

The theory of legitimacy perceives the company and society as parts of a social contract, in that companies operate satisfactorily within the limits that society deems as socially acceptable (O’Donovan, 2002). The theory's underlying assumption is that a two-way influence exists between the authorities and the society in which they operate (Deegan, 2002). From the theory of legitimacy perspective, CSR disclosures can be strategic by providing legitimacy for the company (Patten, 1990; Woodward, Edwards, \& Birkin, 1996) and extrapolating economic goals to add to these social and environmental objectives.

The stakeholder theory considers the company as an organization comprised of both interdependent parts and divergent interests, and suggests that the wealth companies generate is established by their relationships with specific parts of society, rather than the society at large (Carroll, 1979; Donaldson \& Preston, 1995; Jones, 1995). 
This theory aims to align the company's and stakeholders' interests and the disclosure of sustainable information as a means to meet the demands for specific parts by seeking acceptance of their strategies (Gray, Kouhy, \& Lavers, 1995).

Nevertheless, the problem caused by information asymmetry, which allows for the expropriation of wealth from the company's minority shareholders, is the core of agency theory. The agency problem essentially states that managers with opportunistic financial reports tend to disclose CSR activities to compensate for poor-quality gains (Hobson \& Kachelmeier, 2005; Krüger, 2015).

Financial reporting is not only a tool for decision-making, but also an informative mechanism for both managers and shareholders (Moneva \& Llena, 2000). Reports that incorrectly depict the business economy increase the probability that shareholders will not make optimal decisions (Prior et al., 2008). In this context, the EM may be understood as an agency cost, as the EM reduces the quality FRQ (Kinney, Palmrose, \& Scholz, 2004).

From this we can deduce that companies with transparent and reliable financial reports have incentives to disclose as much information as possible, such as information related to CSR activities (Martínez-Ferrero, Garcia-Sanchez, \& Cuadrado-Ballesteros, 2015). On the other hand, opportunistic managers that publish low-quality financial reports have incentives to disclose CSR information, because the disclosure of CSR is a way to externalize the agency problem (Hobson \& Kachelmeier, 2005; Krüger, 2015).

The association between CSR and financial reporting behavior is an empirical question, as recent academic literature has demonstrated. The above arguments indicate that two aspects in this research link CSR to FRQ: the possibility of transparent financial reporting, and the possibility of retreatment.

\subsection{Hypothesis DeVelopment}

Chih et al. (2008), Kim et al. (2012), and Martínez-Ferrero et al. (2015) directly discuss these conflicting hypotheses. After analyzing 1,653 companies in 46 countries, Chih et al. (2008) have provided inconsistent results for different proxies of EM. Martínez-Ferrero et al. (2015) in multi-national research have used measures of DA, accounting conservatism, and the quality of accruals as proxies for FRQ. The authors demonstrated that conservative companies with low levels of EM and/or high-quality accruals tend to present high-quality CSR information.

Several authors used different measurements of the variables and econometric estimators, with different results. For example, Chih et al. (2008) used the Global FTSE4 Good index, while Martínez-Ferrero et al. (2015) used reports' content to identify the level of adherence to the Global Reporting Initiative (GRI) standards, with an ordinal variable valued between zero and three.

Limiting the search to the US market, Kim et al. (2012) investigated whether financial statements differ in companies that are considered socially responsible. This study indicated that CSR companies are less likely to manage results through discretionary accruals and the manipulation of operational activities.

Recent literature has tested various hypotheses involving transparent and retreatment reports in a theoretical framework or, separately, empirically, and concentrated on causal relations in opposite directions: either the FRQ proxies as explanatory of socially responsible enterprises (Choi, Lee, \& Park, 2013; Gao \& Zhang, 2015; Prior et al., 2008); or CSR as a cause of FRQ (Bozzolan, Fabrizi, Mallin, \& Michelon, 2015; Hong \& Andersen, 2011; Muttakin, Khan, \& Azim, 2015; Pyo \& Lee, 2013).

Prior et al. (2008) examined whether companies use CSR to strategically hide EM by applying a proxy CSR from the scores collected by the Sustainable Investment Research International 
Company. The authors captured EM by calculating discretionary accruals and smoothing the results from a multi-country sample of 593 companies between the years 2002 to 2004; these indicated a positive relationship between EM and CSR for regulated companies. However, this result was not statistically significant for non-regulated businesses.

Choi et al. (2013) tested whether corporate governance's size affects the intention to promote CSR managers. To operationalize the research, discretionary accruals were adopted based on the Jones model as modified by Dechow, Sloan, and Sweeney (1995), which used CSR proxies and corporate governance measures. The results indicated a negative relationship between the EM and CSR.

Gao and Zhang (2015) revealed that CSR is desirable in companies and adds a quality dimension. Their empirical data indicated that smoothing companies with high CSR results demonstrate incremental improvement in their yield-return ratios, and have significant, positive relationships with performance measures.

Hong and Andersen (2011) studied whether CSR correlates with FRQ by measuring CSR based on scores from the Kinder, Lydenburg, and Domini index in the North American stock market between 1995 and 2005. The authors noted that socially responsible companies are less likely to manage results.

Pyo and Lee (2013) Korean stock market research adopted the following CSR measures: i) a sustainability reporting disclosure in the standards issued by the GRI, and ii) expenses that include company donations. A regression against these accruals - captured by the discretionary model modified by Dechow et al. (1995) and Kothari, Leone, and Wasley (2005) - and two accounting conservatism measures demonstrated that companies with high donations have less discretionary increase and greater accounting conservatism. Additionally, voluntary reporting on GRI models exhibited a moderating relationship.

Nevertheless, the results appear to be sensitive to shapes of the constructs' measurement proxies. For example, Bozzolan et al. (2015) used an EIRIS-specialized agency's CSR data to collect a sample of companies in 24 countries to demonstrate that CSR activities constrain real manipulation gains. Already, Muttakin et al. (2015), measured a CSR index with twenty categories for a sample of 135 non-financial companies in Bangladesh that managers have lowquality reports when CSR provides further disclosure.

Following the findings in literature and as investigated by Chih et al. (2008), Kim et al. (2012), and Martínez-Ferrero et al. (2015), the hypotheses to be tested in this research pertain to transparent financial reporting $(\mathrm{H} 1 \mathrm{a})$ and retreatment $(\mathrm{H} 1 \mathrm{~b})$ :

H1a: A negative relationship exists between CSR and EM.

H1b: A positive relationship exists between CSR and EM.

\section{RESEARCH DESIGN}

This study's hypotheses were tested using a sample comprised of Brazilian publicly held companies with shares traded on B3 values with data available from the years 2012 to 2016 . Companies from the financial sector and related fields were excluded due to structural, operational, and financial differences.

The sample is composed of 252 different firms, which resulted in 1,181 firm-years composing an unbalanced panel. We obtained financial information from the Economatica ${ }^{\circledR}$ database, then manually extracted the CSR information by company from the published sustainability report for each year of the sample. Table 1 summarizes the selection and sample treatment procedure. 
The extreme values of the sample were treated. The procedure to treat the sample is in accordance with the suggestions in Fávero, Belfiore, Silva, and Chan (2009) and Martins (2002), emphasizing that the outliers can be replaced by the winsorization method. This method, consists of trimming the extreme values on each side of the distribution, replacing them with the smaller and larger values remaining in the distribution. In this study $5 \%$ of the observations were treated $(2.5 \%$ in the lower part and $2.5 \%$ in the upper part).

\subsection{Definition of Variables}

Dependent variable measurement: FRQ. Based on previous literature relating CSR and the FRQ, we adopted DA as a proxy for the DA-FRQ. We use Jones (1991) model to capture the DA in our main tests and adopted the modified version by Dechow et al. (1995) and Kothari et al. (2005) for robust tests. The Jones (1991) model is defined as follows:

$$
\text { TotAccr }_{t} / T A_{t-1}=\alpha_{0}+\alpha_{1}\left(1 / T A_{t-1}\right)+\alpha_{2}\left(\Delta \text { Sales }_{t} / T A_{t-1}\right)+\alpha_{3}\left(P P E_{t} / T A_{t-1}\right)
$$

Considering that TotAccr $r_{t}$ is the total operating accumulation, $\triangle$ Sales $_{t}$ this is the change in revenues in year $(t-1)$ to $t ; P P E_{t}$ is the account property, plant, and equipment gross, and $T A_{t-1}$ is the total assets at the end of the year $(t-1)$.

The total accumulations were calculated by the formula:

TotAccr $_{t}=\left[\left(\Delta C A_{t}-\Delta C A S H_{t}\right)-\left(\Delta C L_{t}-\Delta R L T P_{t}\right)-D A_{t}\right]$, where $\Delta C A_{t}$ is the change in current assets, $\triangle C A S H_{t}$ is the variation in cash, $\triangle C L_{t}$ is the change in current liabilities, $\triangle R L T P_{t}$ is the change in financing and short-term loans, and $D A_{t}$ is the total depreciation and amortization.

Fixed Assets is adopted as a variable to replace the property, plant, and equipment variable according to Martinez (2001), given the nomenclature accepted in the accounting classification of the research environment.

We estimated the model by a cross-section per year, with the DA comprised of the estimates' residuals. The relationship between CSR and FRQ may depend on the measures adopted (Chih et al., 2008). Thus, we re-estimated Jones (1991) model with the modifications suggested by Dechow et al. (1995), and we remove the portion of the accounts receivables' range of variation of revenue. We also applied a suggestion from Kothari et al. (2005) and extracted the performance effect in the calculation.

Variable of interest: D.GRI. We believe that companies are socially responsible according to the standardized level of information disclosed in accordance with the GRI's international guidelines. We followed the approach as posited by Martínez-Ferrero et al. (2015), Nikolaeva and Bicho (2011), and Pyo and Lee (2013).

The variable of interest is a binary variable that assumes a value of one if the companies provide information contained in their sustainability reports - consonant with the highest levels of

Table 1

Selection and Sample Treatment

\begin{tabular}{lc}
\hline Sample selection & Observations \\
\hline All Economatica ${ }^{\circledast}$ companies for the years 2012-2016 & 3,195 \\
Less: companies belonging to the financial sector and related & 800 \\
Less: companies with insufficient data to calculate variables & 1,214 \\
\end{tabular}


sustainability reporting guidelines, or the GRI's version G4 - and a value of zero if the company does not exhibit this feature.

Control variables. Profitability: ROA and ROE. Dechow et al. (1995) note that profitability can correlate with DA. We use accounting measures of financial performance to capture profitability: the return on assets (ROA) and return on equity (ROE). The results regarding yield are mixed, as Choi et al. (2013) and Martínez-Ferrero et al. (2015) found a positive association between CSR and profitability, while Calegari, Chotigeat, and Harjoto (2010) found a positive correlation between yield and EM. Thus, the result per variable is not determinate. We calculate the ROA as the ratio between the variation of net income and total assets, but the ROE is calculated as the ratio between net income and the average change in equity.

Leverage: LEV. Companies with loan restrictions and a greater presence of capital providers can encourage managers to manipulate results. Nevertheless, companies with high debt may have to persuade capital providers by disclosing increasingly more social and environmental information (Solomon \& Lewis, 2002)a standard designed to enable corporate ethical performance to be judged. If such ethical performance is interpreted as social and environmental behaviour our view is that it should lead to more social and environmental disclosure. Yet the willingness to communicate corporate social and environmental performance still seems to be limited. Of the social and environmental disclosures that exist many appear to be rather fragmented and disparate. In this paper we explore the apparent paradox between concern for the environment and the limited amount of corporate environmental disclosure (CED. Previous studies indicate that the leverage related to FRQ can be positive (Bozzolan et al., 2015; Calegari et al., 2010; Cho \& Chun, 2015) or negative (Chih et al., 2008; Litt, Sharma, \& Sharma, 2013). These mixed results do not lead us to anticipate an expected signal. We take the ratio between the current and non-current liabilities and total assets as a debt level proxy.

Growth opportunity: MTB. The opportunity for growth can affect EM (Roychowdhury, 2006), however, we do not anticipate one direction, as previous studies have reported mixed results. The operationalization of opportunity for growth follows the studies Bozzolan et al. (2015), Chih et al. (2008), Cho and Chun (2015), Litt et al. (2013), Martínez-Ferrero et al. (2015) and Muttakin et al. (2015). We take market-to-book ratio as a measure of opportunity for growth.

Firm size: SIZE. The companies' size may be reflected in its financial statements, as larger companies may have more complex statements, and may be a possible source of managerial expropriation (Hochberg, 2012). Alternatively, increased monitoring by shareholders and analysts (Watts \& Zimmerman, 1986) may cause minor EM in larger companies. Thus, the expected sign for this variable is ambiguous. According to Choi et al. (2013), Pyo and Lee (2013), and Scholtens and Kang (2013), we measure size using the natural logarithm of total assets.

\subsection{Model and Analysis Technique}

We capture the relationship between CSR and FRQ as established in the literature and previous research by proposing the following link to test our hypotheses:

$$
F R Q=f(G R I, \text { ControlVariables })
$$

This relationship is empirically tested by the following econometric model:

$$
\begin{gathered}
D A_{i t}\left(\text { or POS.DA } A_{i t}, \text { or NEG.DA } A_{i t}\right)=\beta_{0}+\beta_{1} D \cdot G R I_{i t}+\beta_{2} R O A_{i t}+\beta_{3} R O E_{i t} \\
+\beta_{4} L E V_{i t}+\beta_{5} M T B_{i t}+\beta_{6} S I Z E_{i t}+\varepsilon_{i t}
\end{gathered}
$$


Initially, following Prior et al. (2008) and Pyo and Lee (2013), we estimated the Model 3 with measures of discretionary accruals (DA) as surrogates for earnings management. Previously, because EM may involve either income-increasing or income-decreasing accruals (Klein, 2002; Warfield, Wild, \& Wild, 1995), we re-estimated the Model 3 with the DA's positive (POS.DA) and negative (NEG.DA), as dependents variables. This procedure aims to capture the effect of CSR toward the DA. According Kim et al. (2012), a negative sign between D.GRI and POS. DA will indicate that CSR firms engage less in income-increasing EM; conversely, we interpret a positive relationship between D.GRI and NEG.DA as indicative that CSR firms manage earnings less through accruals.

The hypothesis of transparent financial reporting ( $\mathrm{H} 1 \mathrm{a})$ is supported if $\beta_{1}$ it is negative for models estimated with the dependent variable DA or POS.DA, and positive when the model is estimated with NEG.DA as the dependent variable. The hypothesis retreatment $(\mathrm{H} 1 \mathrm{~b})$ is supported if $\beta_{1}$ is positive, when the model is estimated having a dependent variable DA or POS.DA; and negative when the dependent variable is NEG.DA.

Given the characteristics of the sample chosen to estimate the parameters of Model 3's specifications using the technical panel data, since the longitudinal regression models provide an increased amount of information, and a greater data variability, and a greater efficiency estimation of the parameters. The estimators for this technique have been defined according to their relevant tests. Due to the characteristic of the sample we re-estimate Equation 3 with Tobit models, the non-tabulated results of which didn't present statistically significant differences from the estimated panel.

\section{RESULTS}

\subsection{Descriptive Statistics}

Panel A in Table 2 illustrates the sample's descriptive statistics (see Appendix A for the variables' definition). The DA had negative average values for all specifications, suggesting that companies are more conservative when performing discretionary EM. This corroborates the assumption in the entire sample of other statistics. The frequency of positive DA is greater than its negative occurrence of pairs to the accrual model as captured by Jones (1991), and this is the re-estimation suggested by Dechow et al. (1995). However, the negative accumulations values are on average larger than the positive. The negative DA exhibits higher concentration values in the lowest quartile compared to the upper quartile's positive DA values. Thus, the positive DA are less than the negative DA even with a higher prevalence, causing the average of discretionary accruals to be negative regardless of management's direction; this indicates that managers exhibit more conservative EM practices in the analyzed companies.

The measure of profitability ROA presents negative average, which may reduce the disclosure of transparent financial reporting. However, ROE has positive mean values. This result is evidenced when analyzing the last quartile for this variable. The inverse values between the variables do not allow to identify a clear causal direction of the relationship between profitability and EM. The average debt level is 0.658 , indicating the trend to obtain financing through debt rather than selffinancing, which may reflect in greater monitoring of the company by creditors. The MTB index presents concentrated values in the lower part of the sample, which shows a positive asymmetry (median less than the mean: $0.990<1.826$ ). The positive average result is associated with the size of the maximum values that are larger than their minimum peers. The control variable SIZE 
presented statistical dispersion of data and extreme values in acceptable parameters, indicating homogeneity characteristic and symmetrical distribution.

Table 3 compares the descriptive statistics of firms classified as either socially responsible (CSR) or non-CSR. We define socially responsible firms as those that disclose CSR information as noted in the GRI guidelines, G4 version. This information is captured by the variable D.GRI which assumes the value 1 (one) if the firm has CSR information aligned with the GRI guidelines, G4 version and 0 (zero) otherwise.

The final sample is composed of 252 different firms, resulted in an unbalanced panel of 1,181 firm-years (the 252 firms are not present in all analyzed years). We identify that the dummy variable D.GRI is present in 88 different firms which corresponds to $35 \%$ of the sample. In panel data analysis, it is possible to identify that 236 firm-years are considered CSR versus 945 firm-years non-CSR. The absence of mandatory CSR information justifies this evidence.

In average the positive accumulations (POS.DA) and negative accumulations (NEG.DA) are larger in non CSR firms (Mann-Whitney Test, $\mathrm{p}<0.01$ ). This indicates that EM, regardless of direction, may be greater in firms non-CSR.

Based on the Pearson correlation matrix illustrated in Appendix B, to make the document manageable, neither the dependent nor independent variables' coefficients, without considering the details of the various EM estimates, and those of the independent variables are high, indicating that no multicollinearity problems exist. In detail, POS.DA negatively correlate with the variations in D.GRI $(p<0.01)$. This suggests that opportunistic managers can manipulate earnings to increase profits, accentuating the conflicts of interest.

Table 2

Descriptive Statistics of Selected Variables

\begin{tabular}{lllllllll}
\hline & $\mathrm{n}$ & Mean & Median & Std. & 25th & 75th & Min & Max \\
\hline Dependent Variables & & & & & & & & \\
DA.1991 & 1,181 & -0.009 & 0.005 & 0.119 & -0.061 & 0.056 & -0.341 & 0.256 \\
DA.1995 & 1,181 & -0.009 & 0.002 & 0.123 & -0.061 & 0.056 & -0.357 & 0.275 \\
DA.2005 & 1,181 & -0.013 & 0.000 & 0.124 & -0.064 & 0.049 & -0.377 & 0.274 \\
POS.DA.1991 & 616 & 0.079 & 0.053 & 0.087 & 0.026 & 0.098 & 0.003 & 0.418 \\
POS.DA.1995 & 602 & 0.083 & 0.053 & 0.090 & 0.028 & 0.103 & 0.003 & 0.429 \\
POS.DA.2005 & 589 & 0.080 & 0.049 & 0.091 & 0.025 & 0.099 & 0.002 & 0.428 \\
NEG.DA.1991 & 565 & -0.102 & -0.065 & 0.105 & -0.140 & -0.026 & -0.415 & -0.003 \\
NEG.DA.1995 & 579 & -0.102 & -0.063 & 0.109 & -0.138 & -0.023 & -0.442 & -0.002 \\
NEG.DA.2005 & 592 & -0.103 & -0.064 & 0.108 & -0.140 & -0.026 & -0.443 & -0.002 \\
Control Variables & & & & & & & & \\
ROA & 1,181 & -0.004 & 0.000 & 0.081 & -0.026 & 0.018 & -0.235 & 0.253 \\
ROE & 1,181 & 0.073 & 0.076 & 0.378 & -0.013 & 0.182 & -1.034 & 1.385 \\
LEV & 1,181 & 0.658 & 0.594 & 0.373 & 0.462 & 0.753 & 0.144 & 2.183 \\
MTB & 1,181 & 1.826 & 0.990 & 2.548 & 0.318 & 2.138 & -0.231 & 12.069 \\
SIZE & 1,181 & 21.764 & 21.888 & 1.605 & 20.616 & 22.854 & 18.331 & 24.973 \\
\hline
\end{tabular}

Note. ${ }^{*},{ }^{* *},{ }^{* * *}$ indicates statistical significance at levels of $0.10,0.05$ and 0.01 , respectively. Variables are defined in Appendix A. 
Table 3

Descriptive Statistics by CSR Versus Non-CSR Firms

\begin{tabular}{lcccccccc}
\hline & $\mathrm{n}$ & Mean & Median & $\mathrm{n}$ & Mean & Median & z-test & $\begin{array}{c}\text { Mann-Whitney } \\
\text { Test }\end{array}$ \\
\hline Dependent Variables & & & & & & & & \\
DA.1991 & 236 & 0.002 & 0.011 & 945 & -0.012 & 0.001 & -1.865 & $0.062^{*}$ \\
DA.1995 & 236 & 0.002 & 0.012 & 945 & -0.012 & -0.001 & -1.766 & $0.078^{*}$ \\
DA.2005 & 236 & -0.003 & 0.005 & 945 & -0.016 & -0.003 & -1.573 & 0.116 \\
POS.DA.1991 & 140 & 0.056 & 0.044 & 476 & 0.086 & 0.058 & 3.321 & $0.001^{* * *}$ \\
POS.DA.1995 & 136 & 0.058 & 0.044 & 466 & 0.090 & 0.058 & 3.539 & $0.000^{* * *}$ \\
POS.DA.2005 & 132 & 0.054 & 0.040 & 457 & 0.088 & 0.052 & 3.827 & $0.000^{* * *}$ \\
NEG.DA.1991 & 96 & -0.077 & -0.041 & 469 & -0.107 & -0.072 & -3.380 & $0.001^{* * *}$ \\
NEG.DA.1995 & 100 & -0.075 & -0.035 & 479 & -0.107 & -0.072 & -3.492 & $0.000^{* * *}$ \\
NEG.DA.2005 & 104 & -0.075 & -0.042 & 488 & -0.108 & -0.070 & -3.494 & $0.000^{* * *}$ \\
Control Variables & & & & & & & & \\
ROA & 236 & -0.004 & -0.002 & 945 & -0.004 & 0.000 & 0.267 & 0.789 \\
ROE & 236 & 0.088 & 0.074 & 945 & 0.069 & 0.076 & -0.333 & 0.739 \\
LEV & 236 & 0.626 & 0.619 & 945 & 0.666 & 0.589 & -1.280 & 0.201 \\
MTB & 236 & 2.501 & 1.233 & 945 & 1.658 & 0.902 & -5.134 & $0.000^{* * *}$ \\
SIZE & 236 & 22.899 & 22.853 & 945 & 21.480 & 21.552 & -12.490 & $0.000^{* * *}$ \\
\hline
\end{tabular}

Note. ${ }^{*},{ }^{* *},{ }^{* * *}$ indicates statistical significance at levels of $0.10,0.05$ and 0.01 , respectively. Variables are defined in Appendix A. CSR firms are identified by a dummy variable that takes a value of 1 (one) if the firm has CSR information aligned with the GRI guidelines, G4 version. Non-CSR firms assumed values 0 (zero) for absence of this characteristic. The $\mathrm{p}$ values for Mann-Whitney statistical mean differences test is one-tailed.

\subsection{The Relation between CSR and Discretionary Accruals}

Table 4 lists the results of the estimations from Model 3, including the dependent variables with discretionary accruals in total values (DA), and the positive- (POS.DA) and negative-derived (NEG.DA) Jones (1991) models.

Although the expected direction of causality between CSR and proxies for FRQ, following ethical, political, integrative, and instrumental theories, would support the formulation of the hypotheses of transparent financial reporting and retreatment, we find no relationship between CSR disclosures and manipulation proxies. This suggests that sustainable companies not explain lower or higher levels of DA. In this scenario, we argued that there does not exist an ex-ante incentive on the part of executives to use CSR to conceal or reduce EM in companies. Coffee Jr. (2003)approximately $10 \%$ of all listed companies in the United States announced at least one financial statement restatement. The stock prices of restating companies declined $10 \%$ on average on the announcement of these restatements, with restating firms losing over $\$ 100$ billion in market capitalization over a short three day trading window surrounding these restatements. Such generalized financial irregularity requires a more generic causal explanation than can be found in the facts of Enron, WorldCom or other specific case histories. Several different explanations are plausible, each focusing on a different actor (but none giving primary attention to the board of directors discusses the possible lack of significance in this relationship, since it opposes traditionally researched approaches. The author advocates that it is "perverse" incentives, not a decline in ethics, that cause scandals. Thus, factors related to fraud and professional misconduct would be related to EM. Chih et al. (2008) present arguments and identify them as an institutional hypothesis, 
where factors unrelated to business ethics interfere with the direction and quantity of DA, proxy for EM. This alternative hypothesis shows measures of financial and variable characteristics at the firm level can explain the extent to which companies conduct EM. In part, this was captured with the control variables inserted in the models tested in this research.

Explanations at the operational level can elucidate the lack of significance between CSR and EM. Initially, the lack of consensus in the definition of sustainability is reflected in its operationalization. For example, several authors used different measurements of the variables

Table 4

Multiple Regression of Accrual-Based Earnings Management on CSR

\begin{tabular}{|c|c|c|c|}
\hline \multicolumn{4}{|c|}{ Panel A: Model 3 estimates } \\
\hline & DA.1991 & POS.DA.1991 & NEG.DA.1991 \\
\hline D.GRI & $\begin{array}{l}-0.003(0.008) \\
0.730\end{array}$ & $\begin{array}{l}-0.002(0.008) \\
0.803\end{array}$ & $\begin{array}{l}0.007(0.019) \\
0.716\end{array}$ \\
\hline ROA & $\begin{array}{l}0.0750(0.055) \\
0.170\end{array}$ & $\begin{array}{l}0.117(0.076) \\
0.126\end{array}$ & $\begin{array}{l}-0.115(0.104) \\
0.272\end{array}$ \\
\hline ROE & $\begin{array}{l}-0.002(0.012) \\
0.896\end{array}$ & $\begin{array}{l}0.009(0.019) \\
0.658\end{array}$ & $\begin{array}{l}-0.008(0.015) \\
0.583\end{array}$ \\
\hline LEV & $\begin{array}{l}-0.057(0.011) \\
0.000^{* * *}\end{array}$ & $\begin{array}{l}0.012(0.020) \\
0.548\end{array}$ & $\begin{array}{l}-0.006(0.068) \\
0.931\end{array}$ \\
\hline MTB & $\begin{array}{l}0.003(0.001) \\
0.034^{* *}\end{array}$ & $\begin{array}{l}0.0003(0.001) \\
0.850\end{array}$ & $\begin{array}{l}-0.004(0.005) \\
0.436\end{array}$ \\
\hline SIZE & $\begin{array}{l}0.005(0.002) \\
0.029^{* *}\end{array}$ & $\begin{array}{l}-0.007(0.003) \\
0.009^{* * *}\end{array}$ & $\begin{array}{l}0.037(0.041) \\
0.374\end{array}$ \\
\hline Cons & $\begin{array}{l}-0.075(0.048) \\
0.121\end{array}$ & $\begin{array}{l}0.240(0.057) \\
0.000^{* * *}\end{array}$ & $\begin{array}{l}-0.863(0.913) \\
0.346\end{array}$ \\
\hline Year dummy & Included & Included & Included \\
\hline $\mathrm{n}$ & 1,181 & 616 & 565 \\
\hline $\mathrm{R}^{2}$ & 0.087 & 0.138 & 0.259 \\
\hline $\mathrm{R}^{2}$ adjusted & 0.079 & 0.124 & 0.246 \\
\hline \multicolumn{4}{|l|}{ R-sq } \\
\hline whithin & & & 0.286 \\
\hline between & & & 0.108 \\
\hline overall & & & 0.137 \\
\hline \multicolumn{4}{|c|}{ Panel B: Tests for choosing the estimator } \\
\hline $\mathrm{BP}$ & $0.00[1.000]$ & $1.60[0.103]$ & $6.20[0.006]$ \\
\hline F Chow & & & $1.32[0.011]^{* *}$ \\
\hline Hausman' & & & $24.51[0.006]^{* * *}$ \\
\hline Hausman" & & & $8.16[0.000]^{* * *}$ \\
\hline SH & & & $18.42[0.048]^{* *}$ \\
\hline Estimator chosen & Pooled robust & Pooled robust & Clustered fixed effect \\
\hline
\end{tabular}

Note. ${ }^{*}{ }^{* *},{ }^{* * *}$ indicates statistical significance at levels of $0.10,0.05$ and 0.01 , respectively. Variables are defined in Appendix A. Below the coefficients and standard errors, these in parentheses, the $\mathrm{p}$ values are presented. BP is the Lagrange multiplier of Breusch-Pagan test testing H0: POLS and H1 model random effects. F Chow test confirms the BP test. Hausman' is the Hausman test (H0: random effects; H1: fixed effects). Hausman" is the robust test Hausman described by Hoechle (2007) and Cameron and Trivedi (2010). SH is the Sargan test proposed by Schaffer and Stillmam (2016), which considers the robust standard errors. This test confirms the Hausman'. 
BBR

16

566

and econometric estimators presenting different results. Second, the relationship between CSR and EM can be driven by other factors such as political costs suggested by Yip et al. (2011). Third, the underlying idea of our model is to measure managerial opportunism in the use of CSR disclosures. Nonetheless, we admit the possibility that this effect will be reduced in companies with strong mechanisms of corporate governance. This measure, neglected in this study, could reduce the extent of the use of CSR disclosure in EM.

Despite the limitations and lack of empirical support of the postulated hypotheses, our results resemble recent research. Kolsi and Attayah (2018) and Laksmi and Kamila (2018) found no statistically significant relationship between CSR and EM when analyzing firms from the United Arab Emirates and Indonesia, respectively.

Regarding the control variables, the negative relationship is observed between leverage and DA (coefficient $-0.057, \mathrm{p}<0.01$ ). One explanation for this is that the highest external monitoring, for example due to the greater presence of capital providers, can inhibit EM practices. This relationship conforms to Chih et al. (2008) and Litt et al. (2013).

Growth's opportunity marginal effect, MTB (coefficient $0.003, \mathrm{p}<0.05$ ), indicates that highest market-to-book ratio can manipulate the accumulations, regardless of their direction. This evidence partially aligns with results from Cho and Chun (2015) and Kim et al. (2012).

The SIZE variable positively correlates with DA (coefficient $0.005, \mathrm{p}<0.05$ ) and negatively with positive discretionary accruals, POS.DA (coefficient $-0.007, \mathrm{p}<0.01$ ). Thus, larger companies are likely to practice EM, both to increase and to reduce current earnings. This is consistent with results from Bozzolan et al. (2015), Kim et al. (2012), and Muttakin et al. (2015).

In set, the empirical results do not support the hypotheses raised. However, they are consistent with recent research (e.g. Kolsi \& Attayah, 2018; Laksmi \& Kamila, 2018). Theoretical explanations regarding the sustainability concept, and operational can justify the lack of statistical significance of the main interest variable.

\subsection{Additional Analysis}

Measurements modified from the Jones model (1991). Literature disagrees on a single measurement for FRQ (Dechow, Ge, \& Schrand, 2010). Thus, we re-estimated this by applying Model 3 with Jones modifications, as suggested by Dechow et al. (1995) and Kothari et al. (2005). Table 5 illustrates the results.

The re-estimates' of Model 3 didn't alter the interpretations of the results. The main interest variable (D.GRI) didn't present statistical significance, preventing the acceptance to the hypotheses raised. As discussed in the section 4.2., there appears to be a signal that EM is influenced by firm-level financial and institutional variables.

The relationship between CSR and Real Activities Manipulation (RAM). Chih et al. (2008) report that the relationship between CSR and the accounting information's quality depends on the extent of the EM adopted. Cho and Chun (2015) and Kim et al. (2012) investigated EM motivations through actual activities, with CSR as the variable of interest. To examine whether our results are robust to this alternative measure of FRQ, we re-estimated Model 3, replacing DA, for the magnitude of manipulations of operating activities, calculated according to Roychowdhury (2006).

The results follow those presented in Tables 4 and 5. Thus, it was not possible to validate the hypothesis raised in the research, as justified in sections 4.2.

Analysis of comparable sample. Kim et al. (2012) employ additional essays using a comparable sample. This research adopts a similar technique, by including a sample of comparable companies 
Table 5

Sensitivity Test for Multiple Regression of Accrual-Based Earnings Management on CSR

Panel A: Model 3 re-estimated

\begin{tabular}{|c|c|c|c|c|c|c|}
\hline & $\begin{array}{l}\text { DA. } \\
1995\end{array}$ & $\begin{array}{l}\text { DA. } \\
2005\end{array}$ & $\begin{array}{c}\text { POS.DA. } \\
1995\end{array}$ & $\begin{array}{c}\text { POS.DA. } \\
2005\end{array}$ & $\begin{array}{c}\text { NEG.DA. } \\
1995\end{array}$ & $\begin{array}{c}\text { NEG.DA. } \\
2005\end{array}$ \\
\hline D.GRI & $\begin{array}{c}-0.004 \\
(0.008) \\
0.592\end{array}$ & $\begin{array}{c}-0.004 \\
(0.008) \\
0.653\end{array}$ & $\begin{array}{c}0.002(0.009) \\
0.823\end{array}$ & $\begin{array}{c}0.004(0.009) \\
0.675\end{array}$ & $\begin{array}{c}0.004(0.010) \\
0.705\end{array}$ & $\begin{array}{c}0.008(0.020) \\
0.694\end{array}$ \\
\hline ROA & $\begin{array}{c}0.089 \\
(0.060) \\
0.136\end{array}$ & $\begin{array}{c}0.092 \\
(0.062) \\
0.135\end{array}$ & $\begin{array}{c}0.122(0.085) \\
0.151\end{array}$ & $\begin{array}{c}0.141(0.092) \\
0.124\end{array}$ & $\begin{array}{c}-0.011(0.068) \\
0.875\end{array}$ & $\begin{array}{c}-0.051(0.102) \\
0.622\end{array}$ \\
\hline ROE & $\begin{array}{c}-0.001 \\
(0.013) \\
0.959\end{array}$ & $\begin{array}{c}-0.001 \\
(0.013) \\
0.952\end{array}$ & $\begin{array}{c}0.005(0.020) \\
0.794\end{array}$ & $\begin{array}{c}0.006(0.021) \\
0.772\end{array}$ & $\begin{array}{c}-0.004(0.008) \\
0.602\end{array}$ & $\begin{array}{c}-0.013(0.015) \\
0.385\end{array}$ \\
\hline LEV & $\begin{array}{c}-0.056 \\
(0.011) \\
0.000^{* * *}\end{array}$ & $\begin{array}{c}-0.054 \\
(0.011) \\
0.000^{* * *}\end{array}$ & $\begin{array}{c}0.021(0.023) \\
0.372\end{array}$ & $\begin{array}{c}0.021(0.023) \\
0.375\end{array}$ & $\begin{array}{c}-0.055(0.016) \\
0.001^{* * *}\end{array}$ & $\begin{array}{c}-0.006(0.070) \\
0.932\end{array}$ \\
\hline MTB & $\begin{array}{c}0.004 \\
(0.002) \\
0.009^{* * *}\end{array}$ & $\begin{array}{c}0.004 \\
(0.001) \\
0.015^{* *}\end{array}$ & $\begin{array}{c}-0.0003(0.001) \\
0.823\end{array}$ & $\begin{array}{c}-0.0005 \\
(0.001) 0.751\end{array}$ & $\begin{array}{c}0.002(0.002) \\
0.197\end{array}$ & $\begin{array}{c}-0.002(0.005) \\
0.679\end{array}$ \\
\hline SIZE & $\begin{array}{c}0.005 \\
(0.002) \\
0.017^{* *}\end{array}$ & $\begin{array}{c}0.006 \\
(0.002) \\
0.016^{* *}\end{array}$ & $\begin{array}{c}-0.009(0.003) \\
0.002^{* * *}\end{array}$ & $\begin{array}{c}-0.009(0.003) \\
0.003^{* * *}\end{array}$ & $\begin{array}{c}0.009(0.003) \\
0.001^{* * *}\end{array}$ & $\begin{array}{c}0.042(0.041) \\
0.305\end{array}$ \\
\hline Cons & $\begin{array}{c}-0.088 \\
(0.051) \\
0.083^{*}\end{array}$ & $\begin{array}{c}-0.091 \\
(0.050) \\
0.069^{*}\end{array}$ & $\begin{array}{c}0.290(0.066) \\
0.000^{* * *}\end{array}$ & $\begin{array}{c}0.287(0.067) \\
0.000^{* * *}\end{array}$ & $\begin{array}{c}-0.255(0.060) \\
0.000^{* * *}\end{array}$ & $\begin{array}{c}-0.984(0.911) \\
0.281\end{array}$ \\
\hline Year dummy & Included & Included & Included & Included & Included & Included \\
\hline $\mathrm{n}$ & 1,181 & 1,181 & 602 & 589 & 579 & 592 \\
\hline $\mathrm{R}^{2}$ & 0.087 & 0.072 & 0.141 & 0.159 & 0.253 & 0.245 \\
\hline $\mathrm{R}^{2}$ adjusted & 0.080 & 0.064 & 0.127 & 0.145 & 0.240 & 0.232 \\
\hline \multicolumn{7}{|l|}{ R-sq } \\
\hline whithin & & & 0.136 & 0.168 & 0.265 & 0.250 \\
\hline between & & & 0.129 & 0.131 & 0.256 & 0.125 \\
\hline overall & & & 0.140 & 0.158 & 0.253 & 0.137 \\
\hline
\end{tabular}

Panel B: Tests for choosing the estimator

\begin{tabular}{|c|c|c|c|c|c|c|}
\hline $\mathrm{BP}$ & $\begin{array}{c}0.00 \\
{[1.000]}\end{array}$ & $\begin{array}{c}0.00 \\
{[1.000]}\end{array}$ & $3.18[0.037]^{* *}$ & $2.580[0.054]^{*}$ & $7.49[0.003]^{* * *}$ & $6.84[0.005]^{* * *}$ \\
\hline F Chow & & & $1.48[0.000]^{* * *}$ & $1.47[0.001]^{* * *}$ & $1.34[0.007]^{* * *}$ & $1.33[0.009]^{* * *}$ \\
\hline Hausman' & & & $11.50[0.320]$ & $13.72[0.186]$ & $14.54[0.150]$ & $20.55[0.025]^{* *}$ \\
\hline Hausman" & & & $3.351[0.000]^{* * *}$ & $3.59[0.000]^{* * *}$ & $6.72[0.000]^{* * *}$ & $8.35[0.000]^{* * *}$ \\
\hline \multirow[t]{2}{*}{ SH } & & & $9.05[0.528]$ & $9.97[0.443]$ & $10.12[0.430]$ & $20.06[0.003]^{* * *}$ \\
\hline & $\begin{array}{l}\text { Pooled } \\
\text { robust }\end{array}$ & $\begin{array}{l}\text { Pooled } \\
\text { robust }\end{array}$ & $\begin{array}{c}\text { Clustered } \\
\text { random effect }\end{array}$ & $\begin{array}{c}\text { Clustered } \\
\text { random effect }\end{array}$ & $\begin{array}{c}\text { Clustered } \\
\text { random effect }\end{array}$ & $\begin{array}{l}\text { Clustered fixed } \\
\text { effect }\end{array}$ \\
\hline
\end{tabular}

Note. ${ }^{*},{ }^{* *},{ }^{* *}$ indicates statistical significance at levels of $0.10,0.05$ and 0.01 , respectively. Below the coefficients and standard errors, these in parentheses, the $\mathrm{p}$ values are presented. Variables are defined in Appendix A. BP is the Lagrange multiplier of Breusch-Pagan test testing H0: POLS and H1 model random effects. F Chow test confirms the BP test. Hausman' is the Hausman test (H0: random effects; H1: fixed effects). Hausman" is the robust test Hausman described by Hoechle (2007) and Cameron and Trivedi (2010). SH is the Sargan test proposed by Schaffer and Stillmam (2016), which considers the robust standard errors. This test confirms the Hausman'. 
that integrate the Corporate Sustainability Index (ISE). Calculated since 2005 by B3, ISEs aims to align sustainable development investments and stimulate corporate ethical responsibility to compel companies to provide better-quality sustainable information. We used a control group to form the comparable sample, which enables a comparison of the degrees of FRQ while strengthening the primary sample's findings.

The comparable sample is then constructed as a branch from the main sample, and we selected and analyzed the samples' respective comparable companies by considering the same companies that integrated the ISE in the period. These companies had similar values of total assets and belong to the same economic sector, with similar financial activities. We applied samples proportional to the types of EM to determine the results are robust.

The results presented in Appendix $\mathrm{C}$ re-affirm the previous findings, where there is lack of statistical significance for variable of main interest (D.GRI).

\section{FINAL CONSIDERATIONS}

The growing demand for information about organizations' social behavior and the cost of processing such information provides a better understanding of their motivations to develop CSR information. Companies' reasons for CSR practices may relate to social welfare, based on the legitimacy and stakeholder theories, or may be linked to personal incentives, based on the agency theory. In both cases, the financial accounting information can at least partially capture the motivation behind socially responsible behavior. Thus, we examined whether companies that disseminate high-quality CSR information tend to present different behaviors after their financial reports are published. Two conflicting hypotheses are found in literature: in the transparent financial reporting hypothesis, socially responsible companies tend to present more reliable and transparent financial reporting; and with the possibility of retreatment, opportunistic managers use CSR activities as a tool to hide the harmful impacts of their corporate actions.

We empirically tested the competing hypotheses, and especially the relationship between CSR and FRQ. We believe that companies are socially responsible according to the standardized levels of information disclosed in accordance with the GRI's international guidelines. For FRQ measures, we considered Jones (1991) model and its modifications proposed by Dechow et al. (1995) and Kothari et al. (2005). We used a primary sample of 1,181 firm-years as well as a secondary sample of comparable companies to validate the results, for the years 2012-2016.

In contrast to the hypotheses raised, we didn't find a relationship between the CSR disclosures and the FRQ proxies.

It seems that the CSR disclosure isn't used as a subterfuge to deceive the market when the company prepares poor quality financial reports. Instead, unethical managerial practices (Coffee Jr., 2003)approximately 10\% of all listed companies in the United States announced at least one financial statement restatement. The stock prices of restating companies declined $10 \%$ on average on the announcement of these restatements, with restating firms losing over $\$ 100$ billion in market capitalization over a short three day trading window surrounding these restatements. Such generalized financial irregularity requires a more generic causal explanation than can be found in the facts of Enron, WorldCom or other specific case histories. Several different explanations are plausible, each focusing on a different actor (but none giving primary attention to the board of directors or firm-level financial and institutional characteristics (Chih et al., 2008) may explain the change in EM. Despite these limitations, we believe that our study may be useful for future research investigating managerial opportunism. 
The absence of statistical significance for the main interest variable is maintained in additional EM measurement specifications. They also remain unchanged by substituting competence-based EM by manipulations of operating activities. Estimates with comparable samples also didn't change the interpretations of the results.

Some limitations in our study can be recognized as potential future research. First, given the non-universal acceptance of FRQ measures (Dechow et al., 2010), alternative measures can be used, such as the quality of earnings and accounting conservatism. For example, Martínez-Ferrero et al. (2015) reveal that companies with high-quality financial information tend to be more conservative and have better quality increases. Second, although a causal relationship between CSR and EM exists, a reverse correlation is also possible, as observed by Prior et al. (2008). Thirdly, the complexity in defining the term sustainability should be explored in greater detail, whether in the construction of new metrics or through theoretical alternatives. Finally, our model does not consider the possibility that other variables may interfere in the relationship between CSR and FRQ, such as corporate governance and other company-level features.

\section{REFERENCES}

Bozzolan, S., Fabrizi, M., Mallin, C. A., \& Michelon, G. (2015). Corporate social responsibility and earnings quality: International evidence. The International Journal of Accounting, 50(4), 361-396. https://doi.org/10.1016/j.intacc.2015.10.003

Calegari, M. F., Chotigeat, T., \& Harjoto, M. A. (2010). Corporate social responsibility and earnings reporting. Journal of Current Research in Global Business, 13(20), 1-14.

Cameron, A. C., \& Trivedi, P. K. (2010). Microeconometrics using stata, Revised Edition (2nd ed.). Texas: Stata Press.

Carroll, A. (1979). Three-dimensional conceptual model of corporate performance. The Academy of Managment Review, 4(4), 497-505.

Chih, H.-L., Shen, C.-H., \& Kang, F.-C. (2008). Corporate social responsibility, investor protection, and earnings management: Some international evidence. Journal of Business Ethics, 79(1-2), 179-198. https://doi.org/10.1007/s10551-007-9383-7

Cho, E., \& Chun, S. (2015). Corporate social responsibility, real activities earnings management, and corporate governance: evidence from Korea. Asia-Pacific Journal of Accounting \& Economics, 23(4), 400-431. doi:10.1080/16081625.2015.1047005

Choi, B. B., Lee, D., \& Park, Y. (2013). Corporate social responsibility, corporate governance and earnings quality: Evidence from Korea. Corporate Governance: An International Review, 21(5), 447-467. doi:10.1111/corg. 12033

Coffee Jr., (2003). What caused enron- a capsule social and economic history of the 1990s. Cornell Law Review, 89(214), 1-49. doi:10.2139/ssrn.373581

Dechow, P., Ge, W., \& Schrand, C. (2010). Understanding earnings quality: A review of the proxies, their determinants and their consequences. The Accounting Review, 50(2-3), 344-401. doi:10.1016/j.jacceco.2010.09.001

Dechow, P. M., Sloan, R. G., \& Sweeney, A. P. (1995). Detecting earnings management. The Accounting Review, 70(2), 193-225.

Deegan, C. (2002). Introduction: The legitimising effect of social and environmental disclosures - a theoretical foundation. Accounting, Auditing \& Accountability Journal, 15. doi:10.1108/09513570210435852 
BBR

16

570

Donaldson, T., \& Preston, L. E. (1995). Theory the stakeholder of the corporation: Concepts, evidence, and implications. Management, 20(1), 65-91. doi:10.2307/258887

Fávero, L. P., Belfiore, P., Silva, F. L., \& Chan, B. L. (2009). Análise de dados: modelagem multivariada para tomada de decisóes. Rio de Janeiro: Elsevier.

Fields, T. D., Lys, T. Z., \& Vincent, L. (2001). Empirical research on accounting choice. Journal of Accounting and Economics, 31(1-3), 255-307. doi:10.1016/S0165-4101(01)00028-3

Friedman, M. (1970). The social responsibility of business is to increase its profits. The New York Times Magazine, 13-33.

Gao, L., \& Zhang, J. H. (2015). Firms' earnings smoothing, corporate social responsibility, and valuation. Journal of Corporate Finance, 32, 108-127. doi:10.1016/j.jcorpfin.2015.03.004

Garriga, E., \& Melé, D. (2004). Corporate social responsibility theories: Mapping the territory. Journal of Business Ethics, 53(1/2), 51-71. doi:10.1023/B:BUSI.0000039399.90587.34

Gray, R., Kouhy, R., \& Lavers, S. (1995). Constructing a research database of social and environmental reporting by UK companies. Accounting, Auditing \& Accountability Journal, 8(2), 78-101. doi:10.1108/09513579510086812

Hemingway, C. A., \& Maclagan, P. W. (2004). Managers' personal values as drivers of corporate social responsibility. Journal of Business Ethics, 50(1), 33-44. doi:10.1023/B:BUSI.0000020964.80208. c9

Hobson, J. L., \& Kachelmeier, S. J. (2005). Strategic disclosure of risk prospects: A laboratory experiment. The Accounting Review, 80(3), 825-846. doi:10.2308/accr.2005.80.3.825

Hochberg, Y. V. (2012). Venture capital and corporate governance in the newly public firm. Review of Finance, 16(2), 429-480. doi:10.1093/rof/rfr035

Hoechle, D. (2007). Robust standard errors for panel regressions with cross-sectional dependence. Stata Journal, 7(3), 281-312.

Hoffman, W. M. (1986). What is necessary for corporate moral excellence? Journal of Business Ethics, 5(3), 233-242. doi:10.1007/BF00383631

Hong, Y., \& Andersen, M. L. (2011). The relationship between corporate social responsibility and earnings management: An exploratory study. Journal of Business Ethics, 104, 461-471.

Jones, J. J. (1991). Earnings management during import relief investigations. Journal of Accounting Research, 29(2), 193-228.

Jones, T. M. (1995). Instrumental stakeholder theory: A synthesis of ethics and economics. Academy of Management Review, 20(2), 404-437. doi:10.5465/AMR.1995.9507312924

Kim, Y., Park, M. S., \& Wier, B. (2012). Is earnings quality associated with corporate social responsibility? Accounting Review, 87(3), 761-796. doi:10.2308/accr-10209

Kinney, W. R., Palmrose, Z., \& Scholz, S. (2004). Auditor independence, non-audit services, and restatements: Was the U.S. government right? Journal of Accounting Reasearch, 42(3), 561-588.

Klein, A. (2002). Audit committee, board of director characteristics, and earnings management. Journal of Accounting and Economics, 33(3), 375-400. doi:10.1016/S0165-4101(02)00059-9

Kolsi, M. C., \& Attayah, O. F. (2018). Are socially responsible firms less engaged in earnings management? Evidence from ADX listed companies. International Journal of Business Innovation and Research, 17(4), 536-560. 
Kothari, S. P., Leone, A. J., \& Wasley, C. E. (2005). Performance matched discretionary accrual measures. Journal of Accounting and Economics, 39(1), 163-197. doi:10.1016/j. jacceco.2004.11.002

Krüger, P. (2015). Corporate goodness and shareholder wealth. Journal of Financial Economics, 115(2), 304-329. doi:10.1016/j.jfineco.2014.09.008

Laksmi, A. C., \& Kamila, Z. (2018). The effect of good corporate governance and earnings management to corporate social responsibility disclosure. Academy of Accounting and Financial Studies Journal, 22(1), 1-16.

Lev, B., Petrovits, C., \& Radhakrishnan, S. (2010). Is doing good good for you? how corporate charitable contributions enhance revenue growth. Strategic Management Journal, 31, 182-200. doi: $10.1002 /$ smj. 810

Litt, B., Sharma, D., \& Sharma, V. (2013). Environmental initiatives and earnings management. Managerial Auditing Journal, 29(1), 76-106. doi:10.1108/MAJ-05-2013-0867

Martínez-Ferrero, J., Garcia-Sanchez, I. M., \& Cuadrado-Ballesteros, B. (2015). Effect of financial reporting quality on sustainability information disclosure. Corporate Social Responsibility and Environmental Management, 22(1), 45-64. doi:10.1002/RSC.1330

Martinez, A. L. (2001). “Gerenciamento” dos resultados contábeis: Estudo empírico das companhias abertas brasileiras (Thesis). Faculdade de Economia, Administração e Contabilidade, Universidade de São Paulo.

Martins, G. A. (2002). Estatística geral e aplicada (2nd ed.). São Paulo: Atlas.

Moneva, J. M., \& Llena, F. (2000). Environmental disclosures in the annual reports of large companies in Spain. European Accounting Review, 9(1), 7-29. https://doi.org/https://doi. org/10.1080/096381800407923

Muttakin, M. B., Khan, A., \& Azim, M. I. (2015). Corporate social responsibility disclosures and earnings quality: Are they a reflection of managers' opportunistic behavior? Managerial Auditing Journal, 30(3), 277-298.

Nikolaeva, R., \& Bicho, M. (2011). The role of institutional and reputational factors in the voluntary adoption of corporate social responsibility reporting standards. Journal of the Academy of Marketing Science, 39(1), 136-157. doi:10.1007/s11747-010-0214-5

O’Donovan, G. (2002). Environmental disclosures in the annual report. Accounting, Auditing \& Accountability Journal, 15(3), 344-371. doi:10.1108/09513570210435870

Patten, D. M. (1990). The market reaction to social responsibility disclosures: The case of the Sullivan principles signings. Accounting, Organizations and Society, 15(6), 575-587. doi:10.1016/0361-3682(90)90035-S

Prior, D., Surroca, J., \& Tribó, J. A. (2008). Are socially responsible managers really ethical? Exploring the relationship between earnings management and corporate social responsibility. Corporate Governance, 16(3), 160-177. doi:10.1111/j.1467-8683.2008.00678.x

Pyo, G., \& Lee, H. Y. (2013). The association between corporate social responsibility activities and earnings quality: Evidence from donations and voluntary issuance of RSC reports. Journal of Applied Business Research, 29(3), 945-962.

Roychowdhury, S. (2006). Earnings management through real activities manipulation. Journal of Accounting and Economics, 42(3), 335-370. doi:10.1016/j.jacceco.2006.01.002

Schaffer, M. E., \& Stillmam, S. (2016). Xtoverid: stata module to calculate tests of overidentifying restrictions after xtreg, xtivreg, xtivreg2, Xthtaylor. Boston College Department of Economics: 
BBR

16

572

Statistical Software Components S456779. Retrivied from http://ideas.repec.org/c/boc/bocode/ s456779.html

Scholtens, B., \& Kang, F.-C. (2013). Corporate social responsibility and earnings management: Evidence from Asian economies. Corporate Social Responsibility and Environmental Management, 20(2), 95-112. doi:10.1002/RSC.1286

Solomon, A., \& Lewis, L. (2002). Incentives and disincentives for corporate environmental disclosure. Business Strategy and the Environment, 11(3), 154-169. doi:10.1002/bse.328

Swanson, D. L. (1995). Addressing a theoretical problem by reorienting the corporate social performance model. The Academy of Management Review, 20(1), 43. doi:10.2307/258886

Warfield, T. D., Wild, J. J., \& Wild, K. L. (1995). Managerial ownership, accounting choices, and informativeness of earnings. Journal of Accounting and Economics, 20(1), 61-91. doi:10.1016/0165-4101(94)00393-J

Watts, R. L., \& Zimmerman, J. L. (1986). Positive accounting theory (Englewood Cliffs, Ed.). New Jersey: Prentice-Hall.

Woodward, D. G., Edwards, P., \& Birkin, F. (1996). Organizational legitimacy and stakeholder information provision. British Journal of Management, 7(4), 329-347. doi:10.1111/j.1467-8551.1996.tb00123.x

Yip, E., Staden, C. Van, \& Cahan, S. (2011). Corporate social responsibility reporting and earnings management: The role of political costs. Australasian Accounting, Business and Finance, 5(3), 17-34.

\section{Compliance with Ethical Standards}

Conflict of interest: The authors have no conflicts of interest

Ethical approval: This article does not contain any studies with human participants or animals performed by any of the authors.

Contributions in percentages: First, second, third, and fourth author, 40\%, 20\%, 20\%, and 20\%, respectively. 
Variable Definitions

\begin{tabular}{ll}
\hline Variable & Definition \\
\hline Dependent Variables &
\end{tabular}

DA.1991, 1995 and 2005

Value of discretionary accruals, in which the discretionary accruals are calculated using Jones (1991) model, Jones model modified by Dechow et al. (1995) e Jones model modified by Kothari et al. (2005), respectively.

Positive value of discretionary accruals, in which the discretionary accruals

POS.DA.1991, 1995 and 2005 are calculated using Jones (1991) model, Jones model modified by Dechow et al. (1995) e Jones model modified by Kothari et al. (2005), respectively.

Negative value of discretionary accruals, in which the discretionary accruals

NEG.DA.1991, 1995 and 2005 are calculated using Jones (1991) model, Jones model modified by Dechow et al. (1995) e Jones model modified by Kothari et al. (2005), respectively.

Variable of Interest

D.GRI

Dummy variable that takes a value of 1 (one) if the firm has CSR information aligned with the GRI guidelines, G4 version and 0 (zero) otherwise.

Control Variables

ROA

$\left(L L_{t}-L L_{t-1}\right) / T A_{t}$, where $L L_{t}$ is the net profit at the end of period $t$, $L L_{t-1}$ is the net profit at the end of period $t-1$, and $T A_{t-1}$ is the total assets the end of $t-1$.

ROE $\left(L L_{t} /\left(P L_{t}+P L_{t-1} / 2\right)\right.$, where $L L_{t}$ is the net profit at the end of period $t$, $P L_{t}$ is the equity at the end of period $t$, and $P L_{t-1}$ is the equity at the end of period $t-1$.

LEV Current and non-current liabilities divided by the total assets.

MTB (MVE/BE), where MVE is the market value of equity, and BE is the book value of shareholders' equity.

SIZE Natural logarithm of the total assets of the firms. 
BBR

16

574

\section{APPENDIX B}

Correlation between Selected Variables

\begin{tabular}{|c|c|c|c|c|c|c|c|c|c|c|c|c|c|c|}
\hline & 1 & 2 & 3 & 4 & 5 & 6 & 7 & 8 & 9 & 10 & 11 & 12 & 13 & 14 \\
\hline 1.D.GRI & 1.00 & & & & & & & & & & & & & \\
\hline 2.DA.1991 & 0.05 & 1.00 & & & & & & & & & & & & \\
\hline \multirow[t]{2}{*}{ 3.DA.1995 } & 0.04 & 0.99 & 1.00 & & & & & & & & & & & \\
\hline & & $* * *$ & & & & & & & & & & & & \\
\hline \multirow[t]{2}{*}{ 4.DA.2005 } & 0.04 & 0.98 & 0.99 & 1.00 & & & & & & & & & & \\
\hline & & $* * *$ & $* * *$ & & & & & & & & & & & \\
\hline \multirow[t]{2}{*}{ 5.POS.1991 } & -0.15 & 0.96 & 0.95 & 0.92 & 1.00 & & & & & & & & & \\
\hline & $* * *$ & $* * *$ & $* * *$ & $* * *$ & & & & & & & & & & \\
\hline \multirow[t]{2}{*}{ 6.POS.1995 } & -0.15 & 0.92 & 0.97 & 0.95 & 0.98 & 1.00 & & & & & & & & \\
\hline & $* * *$ & $* * *$ & $* * *$ & $* * *$ & $* * *$ & & & & & & & & & \\
\hline \multirow[t]{2}{*}{ 7.POS.2005 } & -0.16 & 0.90 & 0.95 & 0.97 & 0.97 & 0.99 & 1.00 & & & & & & & \\
\hline & $* * *$ & $* * *$ & $* * *$ & $* * *$ & $* * *$ & $* * *$ & & & & & & & & \\
\hline \multirow[t]{2}{*}{ 8.NEG.1991 } & 0.11 & 0.99 & 0.97 & 0.97 & . & 0.06 & -0.01 & 1.00 & & & & & & \\
\hline & $* *$ & $* * *$ & $* * *$ & $* * *$ & & & & & & & & & & \\
\hline \multirow[t]{2}{*}{ 9.NEG.1995 } & 0.11 & 0.97 & 0.99 & 0.99 & -0.08 & . & 0.33 & 0.98 & 1.00 & & & & & \\
\hline & $* *$ & $* * *$ & $* * *$ & $* * *$ & & & & $* * *$ & & & & & & \\
\hline \multirow[t]{2}{*}{ 10.NEG.2005 } & 0.12 & 0.96 & 0.98 & 1.00 & -0.03 & 0.23 & . & 0.98 & 0.99 & 1.00 & & & & \\
\hline & $* * *$ & $* * *$ & $* * *$ & $* * *$ & & & & $* * *$ & $* * *$ & & & & & \\
\hline \multirow[t]{2}{*}{ 11. ROA } & 0.00 & 0.07 & 0.07 & 0.07 & 0.09 & 0.11 & 0.12 & -0.05 & -0.02 & -0.01 & 1.00 & & & \\
\hline & & $* *$ & $* *$ & $* *$ & $* *$ & $* *$ & $* *$ & & & & & & & \\
\hline \multirow[t]{2}{*}{ 12.ROE } & 0.02 & -0.01 & 0.00 & 0.00 & 0.06 & 0.05 & 0.05 & -0.04 & -0.06 & -0.06 & 0.09 & 1.00 & & \\
\hline & & & & & & & & & & & $* * *$ & & & \\
\hline \multirow[t]{2}{*}{ 13.LEV } & -0.04 & -0.19 & -0.18 & -0.19 & 0.06 & 0.07 & $0.08^{*}$ & -0.24 & -0.24 & -0.24 & -0.01 & 0.10 & 1.00 & \\
\hline & & $* * *$ & $* * *$ & $* * *$ & & $*$ & * & $* * *$ & $* * *$ & $* * *$ & & $* * *$ & & \\
\hline \multirow[t]{2}{*}{ 14.MTB } & 0.13 & 0.09 & 0.11 & 0.11 & 0.03 & 0.03 & 0.04 & 0.08 & 0.08 & 0.09 & 0.07 & 0.17 & -0.13 & 1.00 \\
\hline & $* * *$ & $* * *$ & $* * *$ & $* * *$ & & & & * & * & $* *$ & $* *$ & $* * *$ & $* * *$ & \\
\hline \multirow[t]{2}{*}{ 15.SIZE } & 0.35 & 0.10 & 0.11 & 0.11 & -0.15 & -0.16 & -0.16 & 0.17 & 0.19 & 0.20 & 0.00 & -0.03 & -0.16 & 0.12 \\
\hline & $* * *$ & $* * *$ & $* * *$ & $* * *$ & $* * *$ & $* * *$ & $* * *$ & $* * *$ & $* * *$ & $* * *$ & & & $* * *$ & $* * *$ \\
\hline
\end{tabular}

Note. ${ }^{*},{ }^{* *},{ }^{* * *}$ indicates statistical significance at levels of $0.10,0.05$ and 0.01 respectively. Variables are defined in Appendix A. 


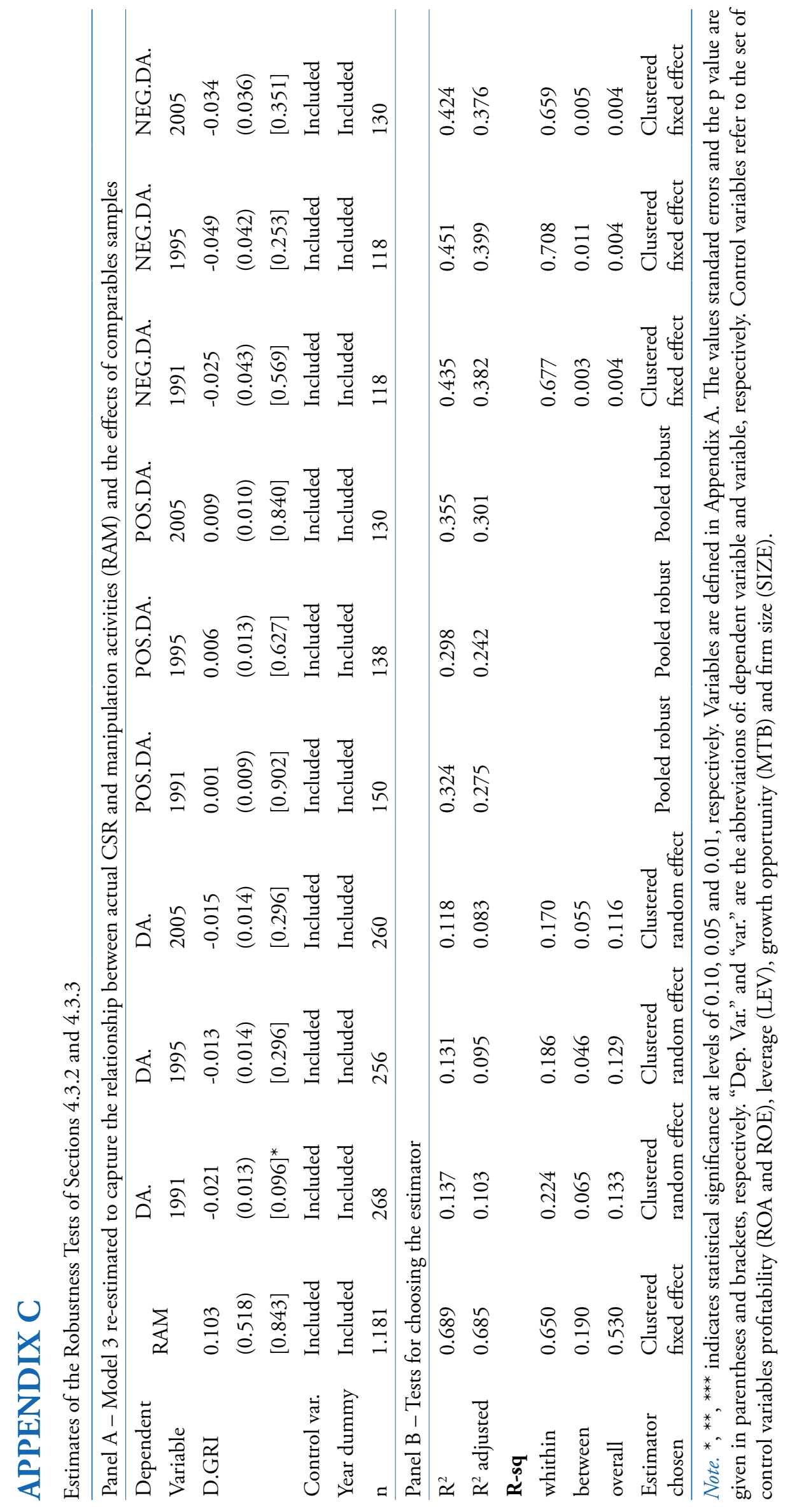

